Journal of Engineering and Applied Sciences 14 (Special Issue 9): 10522-10527, 2019

ISSN: 1816-949X

(C) Medwell Journals, 2019

\title{
A Framework of Halal-Based Operations for Hotel
}

\author{
Mohd Rizal Razalli, Mohd Kamarul Irwan Abdul Rahim and Mohamad Ghozali Hassan \\ School of Technology Management and Logistics, Universiti Utara Malaysia, \\ 06010 Sintok, Kedah, Malaysia
}

\begin{abstract}
Halal tourism is customized towards Muslim tourists based on the Islamic principles known as Maqasid Al-Sharia. Accommodation sector in the halal tourism is also guided by these principles. Despite the increasing demand for the halal-based hotel, there is no established and comprehensive guidelines for its operations. Through a qualitative study, this study provides a guideline named Sharia Islamic Hotel Assessment Tool (SIHAT) which covers a wide range of operational practices of a hotel. The 64-item of SIHAT covers the main operations of hotels namely administration, common areas, bedroom, services and food and beverages. The guideline is hoped to help the halal-based hoteliers to operate according to the Islamic principles as well as for their continuous improvement initiatives.
\end{abstract}

Key words: Halal, hotel operations, sharia compliance, administration, operational, accommodation

\section{INTRODUCTION}

The Halal-based industry which is rapidly expanding, offers opportunities in creating a new market demand not only to Malaysia but also to other Muslim countries worldwide. One of the most dynamically developing among these markets is the market of Halal tourism. Halal tourism becomes a new highlighted product in the tourism industry which provides holiday destinations for Muslim families that governed by the Sharia principles. According to the Master Card-Crescent Rating Global Muslim Travel Index (GMTI), Halal tourism was worth US\$145 billion in 2014 and is expected to continue growing to US\$200 billion by 2020 (Healy, 2015). Halal food is one of the most important factors that influences the choice to visit a particular place and affects tourist attitudes, decisions and behaviour (Henderson, 2008). In fact, scholars have also indicated that Halal food has a big potential to enhance the sustainability of tourism destinations and indeed may represent a competitive advantage (Rand et al., 2003).

In addition, to the food aspect, the Halal tourism is closely linked to the accommodation sector as well. This particular industry is now beginning to offer a Halal-based operations to the customers in order to attract segmented customers from all over the world, especially those from the Muslims countries.

Hotels that introduced the concept of Halal have an added competitive advantage than their rivals. Tourists, especially, those from the Western Asia, Middle East and other Islamic countries are very sensitive in their hotel selection, hence, Halal certified hotels would become more appealing to them compared to the hotels without the certification. Statistics from JAKIM, a government body that is in charge of the Halal matter, showed that in the year 2016, there are 699 hotels in Malaysia have successfully obtained the Halal certification. This number is growing from year to year which reflects the booming sector of the market.

However, Halal-based hotel is a relatively new concept among hoteliers in Malaysia and generally hotel management is still unclear on how to comply with the Sharia principles in their work environment. Additionally, Halal certified hotels are only certified for the food-related section of a hotel while in fact, it should cover the whole institution. Despite the unavailability of clear guidelines of the Halal-based hotel or Sharia compliance, the, so-called Sharia-compliant hotels are increasing in number from year to year.

Furthermore, there is no well-established standard for the Halal-Based Operations for Hotels $(\mathrm{HBOH})$. Hence, this study aims to develop the criteria for the $\mathrm{HBOH}$. The study has reviewed the literature pertaining to the current research in the following four perspectives: financial, operations, marketing and human resource to develop $\mathrm{HBOH}$. Hence, the main aim of the study is to develop a framework for the Halal-based hotel operations.

Model of Halal-based standard: There is no specific, established and comprehensive standard for the Halal-based Hotels in Malaysia. However, there are a few related standards available for hoteliers to conform to the Sharia requirements namely, Malaysian Standards which is certified by SIRIM and Islamic Quality Standard (IQS) which is jointly developed by Universiti Teknologi MARA (UiTM) and Universal Crescent Standard Centre (UCSC). 


\section{J. Eng. Applied Sci., 14 (Special Issue 9): 10522-10527, 2019}

Malaysian Standard (MS): Malaysia has played a leading role in the development of Halal certification, reflecting the Government's objective of developing the country as a hub for Halal food product. JAKIM has taken effort in developing Malaysia Standard and working closely with SIRIM and Department of Standard Malaysia (DSM) in order to coordinate and harmonize the Halal certification process. As a result, a comprehensive Halal food standard called Malaysia Standard with the coded “MS" has been developed, since, July 2004 (Abdul et al., 2008). These standands include.

MS 1500: 2009 Halal food-production, preparation, handling and storage-general guidelines (First revision). This standard contains practical guidelines for the food industry on the preparation and handling of Halal food (including nutrient supplement) and to serve as a basic requirement for food product and food trade or business in Malaysia.

MS 2200: 2008-Islamic consumer goods Part 1: cosmetic and personal care-general guidelines. This standard contains practical guidelines for Halal cosmetic and personal care industry. It serves as a basic requirement for cosmetic and personal care industry and trade or business in Malaysia.

MS 2400: 2010 for Halal logistics. This standard covers the handling of Halal products and includes the transportation, warehousing and retail process.

Manual procedure of Halal certification Malaysia. In general, the scope of this manual procedure covers the application process, inspection, monitoring and enforcement in fulfilling the conditions set for Halal certification in Malaysia. This Halal manual consists of basic uniform principles to be adopted by every Halal certificate owner in Malaysia. It is also a complementary document to MS 1500 and MS 2200.

MS 1900:2005 for quality management systems-requirements from Islamic perspectives. The management quality of an organization based on the Islamic perspective and to meet the certification requirements, each organization or firm is required to appoint a Sharia officer to provide assurance on the compliance of Islamic Sharia for the Halal products and services provided. This Malaysian Standard specifies requirements for a quality management system where an organization needs to demonstrate its ability to consistently provide product that meets customer and applicable regulatory requirements and aims to enhance customer satisfaction through the effective application of the system including processes for continual improvement of the system and the assurance of conformity to customer and applicable regulatory requirements. The significance of MS 1900:2005 is that it focuses on Islamic values and its hold on Islamic principles like ensuring continuous quality and standard of products and quality with the presence of surveillance audit.
MS 2300:2009 for value-based management systems-requirements from an Islamic perspective. This Malaysian Standard consists of a guideline and a certifiable requirements standard which prescribes the framework for an organization to establish a management system based on the Islamic values.

The MS's guideline handbook aims to provide guidelines, rules, methods and regulations for food manufactures in the Halal food preparation and handling in Malaysia. In general, the scope of this MS's guideline involves the application process, inspection, monitoring and enforcement that should be understood and adhered by all Halal certificate owners in fulfilling the conditions set for Halal certification. It also provides a basic requirement for food products, food trade and food business in Malaysia.

Furthermore, this standard is being used by JAKIM as the basis and requirements in complementing the certification process such as procedure for application, auditing and monitoring. The procedure is being used to certify raw materials, ingredients and products based on quality, sanitaryand safety considerations (Hishamuddin, 2007). In order to gain the Halal certification, manufacturers must stick on to a very strict cleanliness and quality controls. However, its implementation needs to be supplemented by other requirements of the certification process (Musa, 2008).

IQS: Islamic Quality Standard for hotel: Another quality standard is known as an Islamic Quality Standard (IQS) for hotel introduced by Othman and Othman (2012). The standard has two main categories, namely the general overview and the detail quality guidance. The areas covered by the standard include basic requirement, overall standard, services food and beverages, bedroom, bathroom and public and external areas. The extent of IQS level is determined by the extent of fulfillment of those 7 mentioned criteria. The quality is assessed using a perception-based scale which is ranged from 'good' to 'very good'. IQS has seven categories or bands of fulfillment ranging from IQS 1-IQS 7. Note that the IQS does not cover the financial and marketing aspects in its assessment.

\section{MATERIALS AND METHODS}

This is a qualitative study. A qualitative research involves a study that does not attempt to quantify the results through statistical summary or analysis. For the purpose of this qualitative study, document reviews and interviews were used as data gathering strategies. This study transformed 'static' information into a dynamic quest for factual confirmation and critical analysis. Thus, in addition to provide the necessary background information on the setting and topic of investigation prior 
to and during the fieldwork, the analysis of documents also helped to select and provide evidences for the study. The documents used in the research include the journals, MS 1900:2005 QMS-requirements from Islamic perspectives, JAKIM website, newspaper archives and other relevant published documents.

\section{RESULTS AND DISCUSSION}

Findings: Based on the extensive literature reviews and interviews, we have developed a framework for Halal-based Operations for hotel known as the Sharia Islamic Assessment Tool (SIHAT). The following section discusses the framework in detail.

Sharia Islamic Hotel Assessment Tool (SIHAT): SIHAT is a proposed tool developed to assess the degree of compliance of Sharia of a hotel. In general, it consists of five hotel oprations, namely administration, common areas, bedroom, services and food and beverages as shown in Fig. 1. They are measured by more specific practices which aligned to the Islamic management and Shariah principles.

These practices are derived from various frameworks such as the Halal certification system by JAKIM, IQS-Islamic Quality Standard for Hotel (Othman and Othman, 2012), Islamic human resource management (Azmi, 2009; Khan et al., 2010), Islamic marketing (Abuznaid, 2012; Hassan et al., 2008) and Islamic finance (Vejzagic and Smolo, 2011). Further, SIHAT has two categories, namely: standard and advanced. The standard category seeks availability of the practices while the advanced category measures the degree of implementation of the practices.

Administration: In the administration section, we consider managerial, financial and human resource practices to be included. There are 15 specific practices used as the measurement. In order to perform an operation in accordance with the Islamic principles, it requires a group of religious advisors which is responsible to monitor hotel operations compliant to the Sharia (Ridzuan and Zahari, 2012). Without proper guidelines in carrying out Halal operations, the goal of Sharia compliant hotels cannot be easily achieved. In regard to the management, hence, we suggest the management to:

- Establish a Sharia advisory committee for purpose of evaluation and monitoring the continuous improvement of compliance

- $\quad$ Set Islamic quality principles as a hotel policy

- Create and monitor the compliance audit

- Implement the improvement program based on the output of the internal audit report
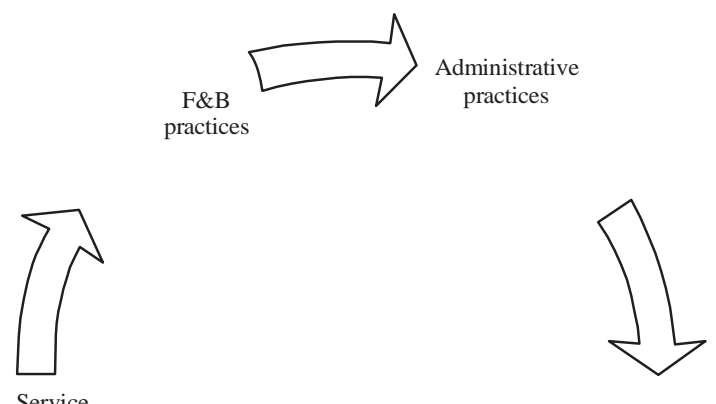

practices

Common areas
practices

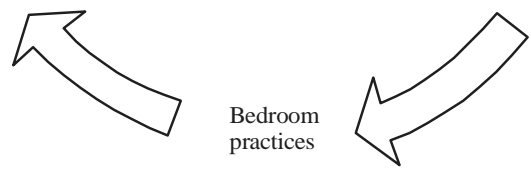

Fig. 1: Framework for the Halal-based operations

In terms of the financial practices, the Shariah-compliant hotel should pay the Zakah (if it is owned by a Muslim) or sponsors a social responsibility program (for a non-Muslim) each year. This suggestion is in line with Rosenberg and Choufany (2012). A hotel should pay a business Zakah when it has fulfilled the conditions for haul (period a year) and Nisab (achieve the required amount of Zakah). The main objective of Zakah is to purify one's wealth and to ensure equal allocation of wealth to everyone (Vejzagic and Smolo, 2011).

In addition, to Zakah, we also suggest the application of Islamic finance in terms of the salary payment, income saving and investment. Muamalat Islam in principle permits any transactions (Qawaid Fiqh) as long as the transactions do not involve prohibited elements such as usury (riba) (Al-Qur’an, Al-Baqarah: 275). Meanwhile, Muamalat Maliah in Islam emphasizes the concepts of Sharia that is used since, the era of Prophet Muhammad (SAW) and his companions up until to the progression of hybrid contracts (combination / mixture) that are presently being used. In addition, Ibn Rusyd and Abu Walid Muhammad b Ahmad Al-Hafid (1981) (16) have identified several Sharia contracts that are used today by the banking industry in Malaysia based on guidelines provided by the Sharia Advisory Council of Bank Negara Malaysia (SAC). These contracts include Mudarabah (profit sharing), Murabahah (cost increase profit), Wadi'ah (saving), Musharakah (joint venture), Al-Bay Bithaman Ajil (BBA) (sales with delayed payment), Wakalah (Agency), Qard Al-Hassan (ihsan loan), Ijarah Thumma Al-Bay' (AITAB-hire purchase), Hibah (reward) and a few more Sharia-based products. Based on the financial Muamalat contract in Malaysia, guidelines of the 
Sharia financial by the Bank Islam Malaysia (BIMB Institute of Reseach and Training, 2005), the Syariah Advisory Council of Bank Negara Malaysia (BNM) and the Syariah Advisory Council of Securities Commission (Securities Commission, 2006) can be used as a foundation for current transactions. The guidelines can also be used to form financial transactions in accordance to Sharia and Mazhab used in Malaysia.

In the case of the hotel industry, financial transactions in hotel involve activities such as the room reservation process, payment of worker's salary, hotel savings and payment of Zakah. For room reservation transaction, Ijarah contract (leasing) and bay' Al-Urban (deposit) can be applied. Meanwhile, for the worker's salary, ujrah (wages) contract which is part from ijarah is deemed suitable for hotels. For income saving, the hotel can choose wadiah/mudharabah accounts offered by any bank in this country. In addition, the hotel also provides various services such as store, laundry and food services. For any form of retail trade, food and laundry services, generally Al-bay' (trade) contract can be applied. Finally, for storage services, Wadiah contract (savings) can be used. For the consistent supply of raw material transactions such as food from the suppliers, Istijrar contract can be highlighted. Istijrar is a supply contract in Islam with the terms and conditions agreed between the two parties.

In terms of human resource, we argue that the management should hire a certain number of Muslim staff and provide suitable resources for them to perform their right as a Muslim. The Islamic concepts such as Tanmiyyah (growth), Jammaah (teamwork), Taqwa (fearful), Ibadah (worship), Tazkiyah Al-Nafs (purifying one's soul), Ta'dib (instilling good manner), Khalifah (vicegerent) and Al-falah (success), Taqlid, Istidlal, Ma'rifah (degree of faith), Tauhid (Allah Oneness and Greatness) are all applicable to organizations (Azmi, 2009). The objective of human resource development in Islam is not only for the knowledge and skills but also for a better spiritual soul of the individual. Here, are our recommendations in terms of human resource:

- $\quad$ At least $30 \%$ of hire should be Muslims

- The Muslims dress code/attire should be imposed

- Provision of prayer room for staff

- Provision of gender specific changing room

- Time allocation for Friday prayer (men) and also routine prayers (men and women)

- Provision of training to staff to be friendly and helpful

- Assurance of safety and security of the staff on the property
Common area: The second section concerns with the public areas in a hotel. Islam is very concerned with the Aurah or the social interaction between men and women. This category also emphasizes the allowable Islamic entertainment and the usage of Halal products. These practices are listed as follows:

- Separate facilities for men and women or at least provision of segregated time slots for men and women. These facilities include the spa, gymnasium, recreational/sport, swimming pool, lounge, lift, toilet and prayer room for guests

- Halal products should be used in common areas such as soap in the toilet

- Assurance of guest safety and security while staying in the hotel

- Provision of Islamic entertainment

- Absence of magic show

- Permitted music such as Nasheed

- Islamic architecture and design should be used in the property (for example, no picture/sculpture of living beings)

Bedroom: The third section is solely applicable to the guest's room. We suggest for the guest rooms to be provided with certain facilities and amenities such as:

- Qiblat direction

- Quran

- Prayer mat

- Prayer schedule

- Bidet

- Halal toiletries

- Halal in-room food

- Islamic in-room entertainment

In addition, to that the room should not have any picture of living beings and alcoholic beverages. We also argue that the hotel to provide smoking and non-smoking room due to smoking is Haram in Malaysia.

Services: The heart of a hotel operation is at the front office department where the customer interact with the hotel services. Hence, the role of the front office in dealing with the Muslim customers is critical. We view the forth section, service practices from the perspective of Islamic marketing and Islamic finance. Among service practices that we suggest include:

- Islamic greeting

- Notification of the banning of alcoholic drink

- Information on Halal restaurant, mosque and groceries

- Wake up call for Subuh prayer

- Available services for additional prayer mat, schedule, etc 


\section{Halal products/services such as:}

- Wedding packages

- Tour

- Seminar/conference

- No gambling products/services

- Halal shopping arcade

- Halal detergent for laundry

\section{Ethical and fair pricing:}

- Price display/information on room, meal and other products

- Absence of price discrimination

\section{Ethical place:}

- Proper location

- Absence of unnecessary delay for customer services

\section{Ethical promotional activities:}

- Absence of sexual appeal

- Absence of manipulation

- Islamic finance transactions

Food and beverages: Our fifth and final section would be food and beverage practices. We suggest the hotel to obtain Halal certification not only for the kitchen but also for its restaurant for all meals including the room services. The certification of Halal program such as in Malaysia would undergo strict guidelines and inspections in various aspects including the food, preparation and storage and handling. This certification would ensure that food available at the hotels is Halal for Muslim consumption. In addition, the Sharia-compliant hotel must not allow any alcoholic drinks to enter the premise.

\section{CONCLUSION}

In conclusion, SIHAT is a framework that covers the operations of Halal-based hotels. It consists of five sections namely, administrative practices, common areas practices, bedroom practices, services practices and F\&B practices. SIHAT can be used as an audit tool for assessing the degree of sharia compliance as well as for continuous improvement for Halal-based hotels.

\section{ACKNOWLEDGEMENTS}

This research was supported by the Ministry of Higher Education under the ERGS Grant.

\section{REFERENCES}

Abdul, T.H., K.A.A. Mohd and K.R. Jamaludin, 2008. Quality assurance in food manufacturing in Malaysia: A preliminary study. Proceeding of International Conference on Mechanical and Manufacturing Engineering, May 20, 2008, Universiti Teknologi Malaysia, Johor, Malaysia, pp: 20-25.

Abuznaid, S., 2012. Islamic marketing: Addressing the Muslim market. Najah Univ. J. Res. Humanities, 26: 1473-1503.

Azmi, I.A.G., 2009. Human capital development and organizational performance: A focus on Islamic perspective. Shariah J., 17: 353-372.

BIMB Institute of Reseach and Training, 2005. In the Islamic concept of Islamic Banking system. BIMB Institute of Reseach and Training Kuala Lumpur BIMB BIRT, Kuala Lumpur, Malaysia.

Hassan, A., A. Chachi and S. AbdulLatiff, 2008. Islamic marketing ethics and its impact on customer satisfaction in the Islamic banking industry. Islamic Econ., 21: 27-46.

Healy, M., 2015. How Halal tourism is travelling in the right direction. The National, Abu Dhabi, UAE.

Henderson, J.C., 2008. Representations of Islam in official tourism promotion. Tourism Culture Commun., 8: 135-145.

Hishamuddin, A., 2007. Community participation and empowerment: An approach for JAKIM halal verification and feedback mechanism. Master Thesis, Universiti Teknologi MARA, Shah Alam, Malaysia.

Khan, B., A. Farooq and Z. Hussain, 2010. Human resource management: An Islamic perspective. Asia Pac. J. Bus. Admin., 2: 17-34.

Musa, N., 2008. Innovation and competitiveness through Halal certification. Proceedings of the 13th International Conference on ISO9000 and TQM, March 24-26, 2008, Universiti Teknologi MARA, Shah Alam, Malaysia, pp: 3-8.

Othman, N. and S. Othman, 2012. IQS-Islamic quality standard for hotel. Universal Crescent Standard Center, Shah Alam, Malaysia.

Rand, G.E.D., E. Heath and N. Alberts, 2003. The role of local and regional food in destination marketing: A South African situation analysis. J. Travel Tourism Marketing, 14: 97-112.

Ridzuan, A.H.A. and M.S.M. Zahari, 2012. Customer awareness towards Syariah Compliant hotel. Proceedings of the 2012 International Conference on Innovation Management and Technology Research (ICIMTR), May 21-22, 2012, IEEE, New York, USA., ISBN:978-1-4673-0655-3, pp: 124-128. 
Rosenberg, P. and H.M. Choufany, 2012. Spiritual lodging-the sharia-compliant hotel concept. HVC, UK. http://www.hvs.com/Content/2856.pdf.

Securities Commission, 2006. [The Shariah advisory council of the securities commission]. Securities Commission, Kuala Lumpur, Malaysia. (In Malay).
Vejzagic, M. and E. Smolo, 2011. Maqasid al-ShariahinIslamic finance: An overview. Proceedings of the 4th Conference on Islamic Economic System, October 11-13, 2011, International Islamic University Malaysia, Kuala Lumpur, Malaysia, pp: 4-5. 